\title{
Inhibitory properties of camel whey protein hydrolysates toward liver cancer cells, dipeptidyl peptidase-IV, and inflammation
}

\author{
Hina Kamal,, Sabika Jafar, ${ }^{*}$ Priti Mudgil, ${ }^{*}$ Chandraprabha Murali, $†$ Amr Amin, $\dagger$ and Sajid Maqsood* \\ *Department of Food Science, College of Food and Agriculture, and \\ †Department of Biology, College of Science, United Arab Emirates University, Al Ain, 15551, United Arab Emirates
}

\begin{abstract}
This report describes an investigation of camel whey protein hydrolysates $(\mathrm{CWPH})$ produced by gastric and pancreatic enzymes for their in vitro antidiabetic, anticancer, and anti-inflammatory properties. Degree of hydrolysis (DH) ranged from 8.54 to $47.53 \%$, with hydrolysates generated using chymotrypsin for $6 \mathrm{~h}$ displaying the highest DH. Reverse phase-HPLC analysis showed that $\alpha$-lactalbumin underwent complete degradation, with no intact $\alpha$-lactalbumin detected in CWPH. The CWPH displayed enhanced antidiabetic activity compared with intact whey proteins; with pepsin- and chymotrypsin-generated CWPH displaying greater inhibition of dipeptidyl peptidase IV (DPP-IV), $\alpha$-glucosidase, and $\alpha$-amylase compared with trypsingenerated CWPH. The highest antiproliferative effect was observed for CWPH generated by chymotrypsin for $3 \mathrm{~h}$, with only 4.5 to $6.5 \%$ viable liver cancer cells (HepG2) remaining when tested at concentrations from 400 to $1,000 \mu \mathrm{g} / \mathrm{mL}$. The highest anti-inflammatory activity was manifested by CWPH generated by pepsin at 6 -h hydrolysis. We report enhanced antiproliferative, antidiabetic, and anti-inflammatory activities upon hydrolysis of camel whey proteins, indicating their potential utilization as bioactive and functional ingredients. Key words: camel whey protein, antiproliferation, antidiabetic, anti-inflammation, functional food
\end{abstract}

\section{INTRODUCTION}

Milk from the one-humped camel (Camelus dromedarius) is widely consumed in arid regions of Asia and Africa. Physiologically, camel milk is easily digested compared with bovine milk; it forms a soft curd in the human stomach, making it suitable as an infant food. The lack of $\beta-L G$ in the camel whey makes it suitable for those who are allergic to cow milk (El-Agamy et

Received February 13, 2018

Accepted June 17, 2018.

${ }^{1}$ Corresponding author: sajid.m@uaeu.ac.ae al., 2009). In addition to its nutritional benefits, camel milk has been used for its medicinal properties, including immunomodulatory, antimicrobial, anticancer, and antidiabetic activities (Abdel Gader and Alhaider, 2016). The therapeutic properties of camel milk against diseases such as diabetes and cancer have been widely studied and reviewed (Agrawal et al., 2007). Among the proteins in the milk, whey proteins are believed to have the highest quality in term of the presence of high content of $\alpha$-LA, lactophorin, immunoglobulins ( $\operatorname{Ig} G$ ), and lactoferrin, even when compared with proteins such as egg, casein, beef, or soy (Lucas, 1999). Camel whey contains greater contents of antimicrobial factors such as lysozyme, lactoferrin, and immunoglobulins compared with bovine milk (El-Agamy et al., 1996). In addition, camel whey contains several immunomodulatory proteins (serum albumin, $\alpha$-LA, lactophorin, and peptidoglycan) that are naturally present or that are part of the primary sequence of whey proteins.

The past decade has seen growing interest in the formulation of functional foods that are not only health-promoting but also effective in reducing the risk of many diseases. Recently, peptides derived from camel milk protein and their potential health-related bioactive properties have been the focus for researchers. Previous studies indicate that camel milk has beneficial effects on treatment of wounds because it enhances wound healing and increases immune cell proliferation and the chemotaxis state of experimental animals (Badr, 2013). It is increasingly recognized worldwide that camel milk consumption helps in prevention and control of diabetes (Agrawal et al., 2007). Camel milk has been demonstrated to be beneficial in reducing the dose of insulin needed to induce glycemic control and increases glycosylate hemoglobin, anti-insulin antibodies, and urinary albumin excretion, and lowers body mass index (Mohamadet al., 2009).

Studies on several human cancer cell lines have shown that milk-derived peptides may act to regulate cell growth, differentiation, and apoptosis. Milk-derived peptides showed interesting chemopreventive effects. In particular, bovine lactoferrin (a whey protein) and buffalo milk waste whey have been demonstrated to inhibit 
the proliferation of breast cancer (MDA-MB-231) and affect the viability of $\mathrm{H}$-Caco-2 cells in in vitro models, respectively (Damiens et al., 1999; De Simone et al., 2011).

So far, studies on camel milk protein hydrolysates have emphasized the antioxidant (Kumar et al., 2016; Salami et al., 2008), antidiabetic (Nongonierma et al., 2017), angiotensin-converting enzyme (ACE)-inhibitory (Moslehishad et al., 2013), and antibacterial activities (Kumar et al., 2016). However, camel whey proteins and their hydrolysates have not received attention with respect to their antidiabetic, anti-inflammatory, and anticancer properties. Exploring camel whey proteins following hydrolysis with gastric and pancreatic enzymes might reveal novel information about their health-related bioactive properties. Therefore, the aim of this work was to investigate the use of camel whey protein hydrolysates (CWPH) as antidiabetic, anticancer, and anti-inflammatory agents upon hydrolysis with gastric and pancreatic enzymes.

\section{MATERIALS AND METHODS}

\section{Chemicals and Reagents}

Pepsin from porcine gastric mucosa (EC 3.4.23.1; 800-2,500 units/mg of protein), trypsin acetylated from bovine pancreas [EC 3.4.21.4; $\geq 40$ Na-benzoylL-arginine ethyl ester (BAEE) units/mg of protein], a-chymotrypsin from bovine pancreas (EC 3.4.21.1; $\geq 40$ units/mg of protein), $\alpha$-glucosidase from Saccharomyces cerevisiae (type I, lyophilized powder $\geq 10$ units/mg of protein), $\alpha$-amylase from porcine pancreas (type VI-B $\geq 5$ units/mg of solid), dipeptidyl peptidase IV (DPP-IV; expressed recombinantly in baculovirusinfected Sf9 cells, $\geq 10$ unit/mg of protein), and all solvents and chemicals used were purchased from SigmaAldrich (St. Louis, MO) and were of analytical grade. One BAEE unit will produce a $\triangle \mathrm{A} 253$ of 0.001 per min at $\mathrm{pH} 7.6$ at $25^{\circ} \mathrm{C}$ using BAEE as substrate. Reaction volume $=3.2 \mathrm{~mL}(1 \mathrm{~cm}$ light path $)$.

\section{Milk Samples}

Raw camel milk from 3 healthy camels of the same breed (Camelus dromedarius) was procured from $\mathrm{Al}$ Ain Dairy farm (Al Ain, United Arab Emirates). Milk was pooled to be used as a single composite (representative) sample for further processing (e.g., separation of whey protein and production of $\mathrm{CWPH}$ ) described below. Camels were reared under semi-intensive conditions and the feeding regimen was approximately the same for all camels on the farm. Milk samples were immediately refrigerated after collection and transferred to the laboratory in the chilled conditions.

\section{Preparation of Camel Whey and Production of CWPH}

Camel milk was skimmed by centrifugation at 2,326 $\times g$ for $20 \mathrm{~min}$ at $10^{\circ} \mathrm{C}$. The skimmed milk was then subjected to acid precipitation at $\mathrm{pH} 4.6$ by the addition of $1 \mathrm{~N} \mathrm{HCl}$, followed by centrifugation at $2,326 \times$ $g$ for 10 min at $4^{\circ} \mathrm{C}$ to separate the whey from caseins. Centrifugation was repeated 2 times to allow efficient separation of whey from casein. Whey samples were then frozen at $-20^{\circ} \mathrm{C}$ for further experiments and used within 3 d. Prepared camel whey protein was adjusted to $3.0 \%$ (wt/vol) by adding ultra-pure water and was divided into 3 batches of $150 \mathrm{~mL}$ for each enzymatic treatment with gastric and pancreatic enzymes (pepsin, trypsin, and $\alpha$-chymotrypsin). The $\mathrm{pH}$ of each whey group was adjusted to the optimum for each enzyme (pH 2 for pepsin using $1 \mathrm{~N} \mathrm{HCl}$; pH 8 for trypsin and chymotrypsin using $1 \mathrm{M} \mathrm{NaOH}$ ). Briefly, to achieve an enzyme:substrate ratio of 1:100, the calculated weight of each enzyme (based on unit activity/mg of enzyme) for $3 \%$ protein in the whey sample was initially dissolved in $5 \mathrm{~mL}$ of whey sample (at optimum $\mathrm{pH}$ ) and then transferred to the whole volume $(150 \mathrm{~mL})$. Each lot of enzyme-added whey was then further divided into 6 tubes of $25 \mathrm{~mL}$ each to represent 3 replicates at each time interval. The hydrolysis of whey protein was then carried out in different batches at the optimal temperature for each enzyme $\left(37^{\circ} \mathrm{C}\right.$ for pepsin; $55^{\circ} \mathrm{C}$ for trypsin and chymotrypsin) in a water bath under constant agitation of $100 \mathrm{rpm}$ (752A model, Fisatom, São Paulo, Brazil). The samples were incubated for 3 and 6 $\mathrm{h}$ of hydrolysis for each enzyme and then the enzymes were deactivated at $95^{\circ} \mathrm{C}$ for $10 \mathrm{~min}$. The samples were centrifuged $\left(10,000 \times g, 15 \mathrm{~min}, 4^{\circ} \mathrm{C}\right)$ and supernatant was collected and stored at $-20^{\circ} \mathrm{C}$ for further analysis which was carried out within 1 wk. The resulting CWPH were designated P3, T3, C3, P6, T6, and C6 for hydrolysates generated by pepsin, trypsin, and chymotrypsin after 3 and $6 \mathrm{~h}$ of hydrolysis, respectively.

\section{Characterization of CWPH}

Degree of Hydrolysis. Degree of hydrolysis (DH) was analyzed using the o-phthaldialdehyde (OPA) method described by Nielsen et al. (2001) with a few modifications. The OPA reagent was freshly prepared by mixing $25 \mathrm{~mL}$ of sodium tetraborate buffer (100 $\mathrm{m} M$; $\mathrm{pH} 9.3), 2.5 \mathrm{~mL}$ of SDS (20\%, wt/wt), $40 \mathrm{mg}$ of OPA (dissolved in $1 \mathrm{~mL}$ of methanol), and $100 \mu \mathrm{L}$ of $\beta$-mercaptoethanol. The final volume was made up to $50 \mathrm{~mL}$ with ultra-pure water obtained with a MilliQ equipment (Elix-10, Millipore, Molsheim, France). A small aliquot $(100 \mu \mathrm{L})$ of each sample was added directly to a cuvette containing $1 \mathrm{~mL}$ of OPA reagent 
and mixed gently for $5 \mathrm{~s}$. The absorbance was measured at $340 \mathrm{~nm}$ using a Nova-Spec-II Spectrophotometer (Pharmacia, London, UK) after 2 min of incubation in the dark at room temperature.

Degree of hydrolysis was determined by using following equation: $\mathrm{DH}(\%)=h / h_{\text {tot }} \times 100$, where $h_{\text {tot }}$ is the total number of peptide bonds per protein equivalent and $h$ is the number of hydrolyzed bonds, which was determined by using $h=\left(\right.$ serineNH $\left.\mathrm{N}_{2}-\beta\right) / \alpha$, where $\alpha$, $\beta$, and $h_{\text {tot }}$ values were $1.039,0.383$, and $8.2 \mathrm{mEq} / \mathrm{g}$ of protein, respectively (Nielsen et al., 2001).

Reverse-Phase HPLC. The method described by Bobe et al. (1998) was used, with slight modifications, to characterize the nonhydrolyzed and hydrolyzed camel whey proteins on a reverse phase (RP)-HPLC system (Thermo Scientific, Germering, Germany). Protein analysis was performed on a reversed phase column C-18 (250 mm long $\times 4.6 \mathrm{~mm}$ internal diameter; Thermo Scientific). Camel whey and whey hydrolysate samples (3\%, wt/vol, protein concentration) were mixed with solvent [acetonitrile, water, and trifluoroacetic acid (TFA) in a ratio 100:900:1 ( $\mathrm{vol} / \mathrm{vol} / \mathrm{vol})$ ], and insoluble particles were removed by filtration over a $0.45-\mu \mathrm{m}$ cellulose acetate filter. The filtrate was injected $(5 \mu \mathrm{L})$ on the column. Chromatographic separation was performed in reverse-phase mode using a C-18 column maintained at $25^{\circ} \mathrm{C}$ with a flow rate of $1 \mathrm{~mL} /$ min, using a linear acetonitrile gradient, starting with 2.5 min of $100 \%$ buffer A (water, $0.13 \%$ TFA), followed by a linear gradient to $40 \%$ buffer B (100\% acetonitrile, $0.13 \%$ TFA) for $10 \mathrm{~min}$. The detection wavelength was $220 \mathrm{~nm}$. Analysis of CWPH produced by different enzymes for 3 and $6 \mathrm{~h}$ was carried out. For identification of milk proteins, bovine whey protein standards $(>90 \%$ purity; Sigma-Aldrich) were prepared and injected.

\section{Antidiabetic Activity of CWPH}

DPP-IV Inhibition Assay. The inhibitory activity of CWPH against DPP-IV was assessed according to the method described by Lacroix and Li-Chan (2013), with some modifications. Briefly, $25 \mu \mathrm{L}$ of Gly-Pro- $p$ nitroanilide $(1.6 \mathrm{mM})$ and $25 \mu \mathrm{L}$ of sample (or $25 \mu \mathrm{L}$ of PBS for control samples) were incubated at $37^{\circ} \mathrm{C}$ for $10 \mathrm{~min}$. Then, the reaction was initiated by adding 50 $\mu \mathrm{L}$ of DPP-IV $(8 \mathrm{U} / \mathrm{L})$ and the mixture was incubated at $37^{\circ} \mathrm{C}$ for $60 \mathrm{~min}$. The reaction was terminated by adding $100 \mu \mathrm{L}$ of $1 M$ sodium acetate buffer ( $\mathrm{pH} 4.0$ ), and the absorbance of the samples was measured at $405 \mathrm{~nm}$ using a microplate reader (Epoch 2, BioTek, Winooski, VT). The control reaction (without CWPH) representing $100 \%$ enzyme activity was also carried out in the similar way. The percent inhibition of enzyme activity was calculated as follows:

$$
\text { Enzyme inhibition }(\%)=\left[1-\left(\frac{C-D}{A-B}\right)\right] \times 100 \text {, }
$$

where $A$ (control), $B$ (control blank), $C$ (sample), and $D$ (sample blank) refer to the absorbance values of reaction vials containing live enzyme and buffer, dead enzyme and buffer, live enzyme and sample, and dead enzyme and sample, respectively. Substrate was present in all reactions.

$\boldsymbol{\alpha}$-Amylase Inhibition Assay. The CWPH were evaluated for $\alpha$-amylase inhibitory activity following a previously reported method with slight modification (Chinedum et al., 2018). Briefly, $40 \mu \mathrm{L}$ of sample in a 1.5-mL Eppendorf tube was added to $160 \mu \mathrm{L}$ of distilled water and $400 \mu \mathrm{L}$ of $0.5 \%$ starch and the mixture was vortexed for $10 \mathrm{~s}$. After adding $200 \mu \mathrm{L}$ of the enzyme solution $(30 \mathrm{U} / \mathrm{mL})$ to the mixture, the tubes were incubated at $25^{\circ} \mathrm{C}$ for $3 \mathrm{~min}$. Then, $200 \mu \mathrm{L}$ of the mixture was taken and added to a separate tube, which contained $100 \mu \mathrm{L}$ of 3,5-dintrosalicyclic acid (DNS) color reagent solution (96 mM 3,5-dinitrosalicylic acid, 5.31 $M$ sodium potassium tartrate in $2 \mathrm{M} \mathrm{NaOH})$. The tube was placed into a $95^{\circ} \mathrm{C}$ thermo mixer (Eppendorf, Hamburg, Germany) for 10 min to inactivate the $\alpha$-amylase. Then, $200 \mu \mathrm{L}$ of the mixture was taken and added into a 96-well plate. The absorbance of the reaction mixture was measured at $540 \mathrm{~nm}$. To eliminate the background absorbance, an appropriate control without enzyme was included. Type- $1 \alpha$-amylase inhibitor from acarbose was analyzed as a positive control. The percent inhibition values were calculated using Equation [1].

$\alpha$-Glucosidase Inhibition Assay. The $\alpha$-glucosidase inhibitory activity of $\mathrm{CWPH}$ was determined according to a previously reported method with slight modifications (Zhang et al., 2015). In brief, $80 \mu \mathrm{L}$ of sample was mixed with $100 \mu \mathrm{L}$ of $10 \mathrm{mM}$ 4-nitrophenyl- $\beta$-D-glucopyranoside $(p \mathrm{NPG})$ solution (dissolved in $0.1 M$ phosphate buffer, $\mathrm{pH}$ 6.8) in a $1.5-\mathrm{mL}$ centrifuge tube, and $20 \mu \mathrm{L}$ of $1 \mathrm{U} / \mathrm{mL}$ enzyme solution was added to start the reaction at $37^{\circ} \mathrm{C}$ for $10 \mathrm{~min}$. After $10 \mathrm{~min}, 200 \mu \mathrm{L}$ of the reaction mixture was taken and added to a 96 -well plate. The release of $p$-nitrophenol from $p$ NPG was measured at $405 \mathrm{~nm}$. The percent inhibition values were calculated using Equation [1].

\section{Anticancer Activities of CWPH Toward a Liver Cancer Cell Line}

The anticancer activity (cytotoxicity) of CWPH samples toward a liver cancer cell line (HepG2 cells) was determined by the 3-(4,5-dimethyl thiazol-2yl)-2,5diphenyl tetrazolium bromide (MTT) assay (Horiuchi 
et al., 1988). The HepG2 cells $\left(1 \times 10^{5}\right.$ cells/well $)$ were plated in $200 \mu \mathrm{L}$ of medium/well in 96-well plates. After attachment, complete growth medium was replaced by medium ranging from 50 to $1,000 \mu \mathrm{g} / \mathrm{mL}$ of each CWPH and allowed to incubate for $24 \mathrm{~h}$. For the assay, MTT reagent $(5 \mathrm{mg} / \mathrm{mL})$ was added to each well and the plate was incubated for 3 to $4 \mathrm{~h}$ in a $5 \% \mathrm{CO}_{2}$ incubator. After incubation, the medium was removed and $100 \mu \mathrm{L}$ of dimethyl sulfoxide (DMSO, solubilizing reagent) was added to each well and mixed well by micropipette. The presence of viable cells was visualized by the development of purple color due to the formation of formazan crystals. The optical density (OD) values were read at $595 \mathrm{~nm}$, with DMSO as a blank and cell without any treatment as control using the GloMax microplate reader (Promega, Madison, WI). Optical densities were read and the concentrations of protein required to produce a $50 \%$ inhibition of the initial rate of reaction $\left(\mathbf{I C}_{50}\right)$ was determined graphically by plotting the concentration of the drug (x-axis) against the relative cell viability (y-axis):

$$
\text { Cell viability }(\%)=\left(\frac{\text { Mean sample OD }}{\text { Control OD }}\right) \times 100 \text {. }
$$

\section{Anti-Inflammatory Activity Assay}

Anti-inflammatory activity was determined according to the method described by Aguilar-Toalá et al. (2017) with some modifications. Briefly, the reaction mixture $(250 \mu \mathrm{L})$ consisted of $50 \mu \mathrm{L}$ of egg albumin (from fresh hen egg), $100 \mu \mathrm{L}$ of PBS (pH 6.4), and 100 $\mu \mathrm{L}$ of sample in a 96 -well microplate. A similar volume of double-distilled water served as control. The reaction mixtures were incubated at $37^{\circ} \mathrm{C}$ for $15 \mathrm{~min}$ and then heated at $70^{\circ} \mathrm{C}$ for another $5 \mathrm{~min}$ to deactivate the reaction. Absorbance was measured at $600 \mathrm{~nm}$ in a microplate reader (Epoch 2, BioTek). Diclofenac sodium at a final concentration of 100 to $2,500 \mu \mathrm{g} / \mathrm{mL}$ was used as the reference drug and treated similarly for preparation of standard curve. The results are expressed as diclofenac sodium equivalent capacity (DSEC)/mg of protein equivalent.

\section{Statistical Analysis}

Camel whey proteins prepared from milk of 3 camels were pooled and hydrolyzed separately to produce 3 sets of hydrolysates for each enzyme tested, which served as 3 replicates. All parameters were analyzed in triplicate. The data were subjected to one-way ANOVA using SPSS 12.0 software (SPSS Inc., Chicago, IL). Significant treatment means were separated by Duncan's new multiple range test.

\section{RESULTS AND DISCUSSION}

\section{Characterization of CWPH}

Degree of Hydrolysis. Enzymatic hydrolysis of proteins results in the degradation of major proteins and release of small peptides and free amino acids, which are known to contribute significantly to the nutritional value and bioactive properties of food proteins. Monitoring the extent of hydrolysis is very important to control the hydrolysis process, which is known affect the functional and bioactive properties of the hydrolysates. The DH of CWPH produced by pepsin, trypsin, and chymotrypsin after 3 and $6 \mathrm{~h}$ of hydrolysis is shown in Figure 1a. The DH for each CWPH increased proportionally with time of hydrolysis from 3 to $6 \mathrm{~h}$. The DH of camel whey proteins ranged between 8.54 and $47.53 \%$ with C6 hydrolysates displaying the highest DH (47.53\%) followed by P6 (24.58\%) and T6 (14.49\%) CWPH. The DH value reflects the content of shorter peptides released: the higher the $\mathrm{DH}$, the more shorter peptides released (Morais et al., 2005). The significant difference $(P<0.05)$ in $\mathrm{DH}$ among the hydrolysates produced could be attributed to the rate of enzymatic reaction or the specific action of enzyme and substrate affinity (Dryakova et al., 2010).

\section{Characterization of CWPH by RP-HPLC}

The HPLC chromatogram of camel whey and CWPH generated with pepsin, trypsin, and chymotrypsin after 3 and $6 \mathrm{~h}$ is shown in Figure 1b. In the intact camel whey protein samples, an intact peak belonging to $\alpha$-LA was detected at $5.5 \mathrm{~min}$ retention time. After hydrolysis with different enzymes for different time periods, the major whey protein in camel whey $(\alpha-\mathrm{LA})$ underwent complete degradation and no intact proteins could be seen in the chromatogram of the CWPH. Different smaller peptide peaks were eluted mainly between 2.5 and 4.6 min retention time, indicating that the CWPHgenerated peptides have a wide range of hydrophobicity and molecular weight. Nongonierma et al. (2017) also reported that different peptide peaks eluted throughout the chromatogram, indicating that camel milk protein hydrolysates contained peptides having a wide range of hydrophobicity. Higher hydrolysis with generation of smaller peptides was observed in chymotrypsin (C3 and C6) and pepsin (P3 and P6) generated $\mathrm{CWPH}$, which was also reflected from the DH results (Figure 1a), where pepsin and chymotrypsin displayed higher $\mathrm{DH}$ than trypsin-generated hydrolysates. However, trypsin (T3 and T6) portray some traces of $\alpha$-LA and lesser amounts of small peptides were generated as shown in Figure 1b. Previous reports on camel milk protein hy- 
drolysate analyzed by RP-HPLC showed that no intact protein could be seen in the peptide profile of hydrolysate produced by trypsin (Nongonierma et al., 2017).

\section{Antidiabetic Properties of CWPH}

Given the high prevalence of type 2 diabetes (estimated to affect 370 million people; $\mathrm{Hu}, 2011$ ), different strategies are being devised to properly manage hyperglycemia, and dietary intervention is gaining importance as a way to manage type 2 diabetes (Kahn et al., 2014). Oral administration of whey proteins and their hydrolysates positively affects blood glucose levels and insulinotropic responses in humans (Jakubowicz and Froy, 2013). Proteins from diverse sources are considered precursors for peptides with DPP-IV inhibitory properties (Nongonierma et al., 2018). Furthermore, in silico approaches have revealed that several peptides encrypted within the AA sequences of dietary proteins, including bovine, ovine, and caprine whey proteins, could act as DPP-IV inhibitors. Therefore, whey proteins from novel sources such as camel milk need to be explored for their potential antidiabetic effects.

Inhibition of DPP-IV by $C W P H$. Bovine caseinand whey-derived bioactive peptides are well studied for their DPP-IV inhibitory activities. Even though DPPIV inhibitory peptides can be generated from various food proteins, one recent study has demonstrated the DPP-IV inhibitory potential of camel milk protein hydrolysates and none have determined whether $\mathrm{CWPH}$ have DPP-IV inhibitory potential (Nongonierma et al., 2017). The DPP-IV inhibitory activity demonstrated by CWPH generated in this study is shown in Figure 2. The hydrolysis of camel whey proteins with different enzymes enhanced DPP-IV inhibition activity 3 - to 4 -fold compared with unhydrolyzed whey proteins $(P$ $<0.05)$. Peptic CWPH showed the highest DPP-IV inhibition $(96 \% \pm 2.8$ and $92.9 \% \pm 4.5)$ after 3 and 6 $\mathrm{h}$, respectively, followed by trypsin- and chymotrypsingenerated CWPH. In the study by Nongonierma et al. (2017), camel milk protein hydrolysates generated with trypsin had increased DPP-IV inhibitory activity compared with unhydrolyzed camel milk proteins and bovine milk protein hydrolysates. In that study, potent and unique DPP-IV inhibitory peptides (LPVPQ and WK) were identified in camel milk protein hydrolysates that were not present in bovine milk protein hydrolysates. Previously, tryptic hydrolysates of bovine whey proteins were reported to decrease blood glucose in mice compared with controls after an oral glucose tolerance test. The tryptic hydrolysates were able to inhibit DPP-IV in vitro as well $\left(\mathrm{IC}_{50}\right.$ of $\left.210 \mu \mathrm{M}\right)$, and the peptide VAGTWY was thought to be the major compound responsible for this effect (Uchida et al., a)
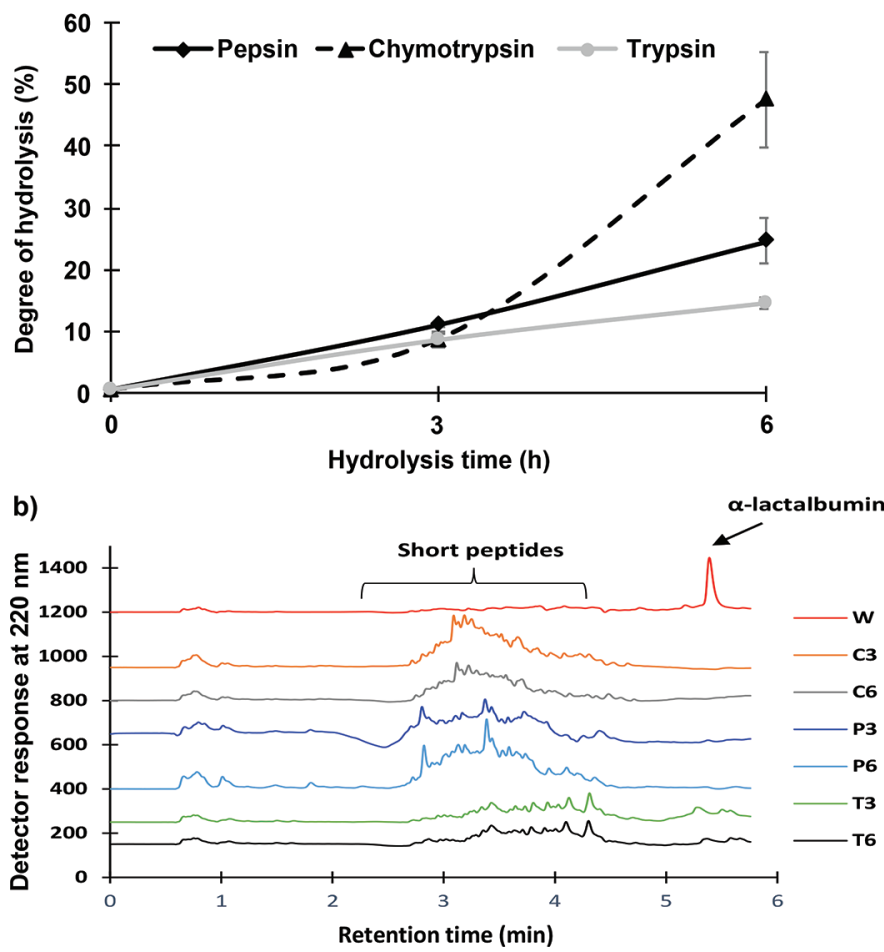

Figure 1. (a) Degree of hydrolysis, and (b) reverse-phase (RP)HPLC profile of camel whey protein hydrolysates generated with pepsin, trypsin, and chymotrypsin after 3 and $6 \mathrm{~h}$ of hydrolysis (P3, T3, $\mathrm{C} 3, \mathrm{P} 6, \mathrm{~T} 6$, and $\mathrm{C} 6$, respectively; $\mathrm{W}=$ unhydrolyzed whey). The error bars for panel a denote $\mathrm{SD}(\mathrm{n}=3)$. Color version available online.

2011). Moreover, a tryptic hydrolysate from bovine whey protein concentrate was reported to inhibit DPPIV activity, with an $\mathrm{IC}_{50}$ value of $1.51 \mathrm{mg} / \mathrm{mL}$ (Silveira et al., 2013). Trypsin-derived $\beta$-LG-rich whey protein hydrolysate was fractionated by semi-preparative RPHPLC, and 2 of the 6 fractions obtained showed high DPP-IV inhibitory activity, with $\mathrm{IC}_{50}$ values of 367.3 and $86.0 \mu \mathrm{g} / \mathrm{mL}$, respectively (Silveira et al., 2013). In the present study, all hydrolysates showed similar DPP-IV inhibitory activity $(P>0.05)$ except P3 and T3, which demonstrated the highest and lowest inhibitory activities $(P<0.05)$, respectively. Therefore, our results and those of previous studies on bovine whey protein hydrolysates indicate that gastric and intestinal enzymes such as pepsin, chymotrypsin, and trypsin have potential to generate hydrolysates with enhanced DPP-IV inhibitory activity. This indicates that camel whey proteins might have antidiabetic effects after gastric and intestinal digestion upon consumption.

Inhibition of $\alpha$-Glucosidase and $\alpha$-Amylase. An additional method to manage type 2 diabetes is the inhibition of carbohydrate-hydrolyzing enzymes, such as $\alpha$-glucosidase and $\alpha$-amylase, which discharge monosaccharides from complex carbohydrates. Inhib- 
8716

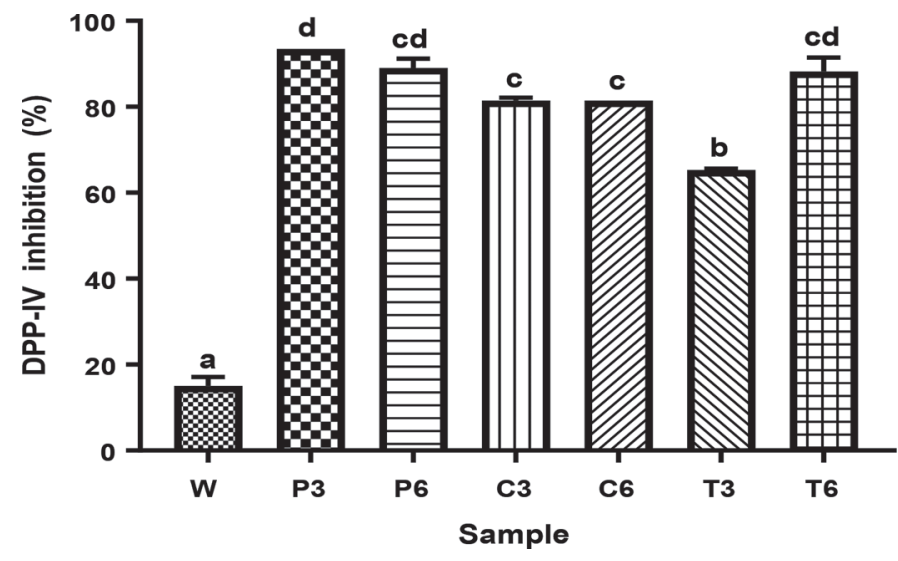

Figure 2. Dipeptidyl peptidase-IV (DPP-IV) inhibition demonstrated by camel whey protein hydrolysates $(\mathrm{CWPH})$ generated with pepsin, trypsin, and chymotrypsin after 3 and $6 \mathrm{~h}$ of hydrolysis (P3, T3, C3, P6, T6, and C6, respectively; $\mathrm{W}=$ unhydrolyzed whey). The concentration of protein in the CWPH was 3\% (wt/vol). Data represent mean $\pm \mathrm{SD}(\mathrm{n}=3)$ from 3 replicates. Different letters $(\mathrm{a}-\mathrm{d})$ on bars represent significant differences among CWPH.

iting the activity of enzymes such as $\alpha$-amylase and $\alpha$-glucosidase is an important strategy to decrease postprandial hyperglycemia (Kahn et al., 2014). In the current study, we report, for the first time, the inhibitory potential of whey protein hydrolysates toward $\alpha$-glucosidase and $\alpha$-amylase. Figures 3 and 4 show inhibition of $\alpha$-glucosidase and $\alpha$-amylase, respectively, by CWPH.

The pepsin- and chymotrypsin-generated hydrolysates had the highest and trypsin-generated hydrolysates the lowest $\alpha$-glucosidase inhibition $(P<0.05$; Figure 3$)$. The P3 CWPH showed the highest inhibition activity (78.59\%), followed by $\mathrm{C} 3(77.88 \%)$ and $\mathrm{C} 6(77.45 \%)$;

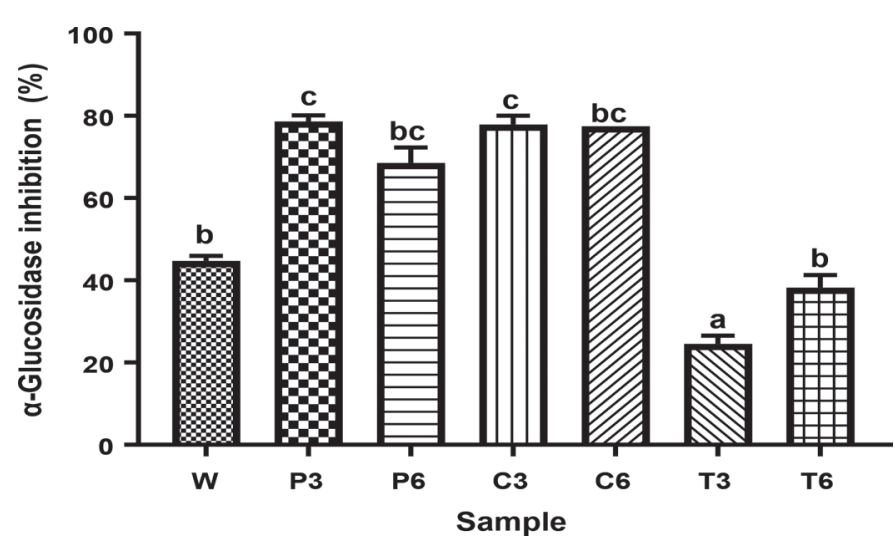

Figure 3. $\alpha$-Glucosidase inhibitory activities of camel whey protein hydrolysates $(\mathrm{CWPH})$ generated with pepsin, trypsin, and chymotrypsin after 3 and $6 \mathrm{~h}$ of hydrolysis (P3, T3, C3, P6, T6, and C6, respectively; $\mathrm{W}=$ unhydrolyzed whey). The concentration of protein in the CWPH was $3 \%(\mathrm{wt} / \mathrm{vol})$. Data represent mean $\pm \mathrm{SD}(\mathrm{n}=3)$ from 3 replicates. Different letters $(\mathrm{a}-\mathrm{c})$ on bars represent significant differences among CWPH. these values did not differ significantly. Lacroix and Li-Chan (2013) showed that peptic hydrolysates of bovine whey protein isolate, $\beta-\mathrm{LG}$, and $\alpha-\mathrm{LA}$ at 2.5 $\mathrm{mg} / \mathrm{mL}$ inhibited $\alpha$-glucosidase by 36,33 , and $24 \%$, respectively, whereas the nonhydrolyzed counterparts showed no enzyme inhibition. However, in the present study, nonhydrolyzed camel whey proteins had higher $\alpha$-glucosidase inhibitory activity than T3 hydrolysates $(P<0.05)$. Egg albumin hydrolysate generated by Alcalase (Sigma-Aldrich) was reported to yield peptides KLPGF and NVLQPS with $\alpha$-glucosidase inhibitory activity $\left(\mathrm{IC}_{50}\right.$ values of $59.5 \pm 5.7$ and $100.57 \mu \mathrm{mol} / \mathrm{L}$, respectively; $\mathrm{Yu}$ et al., 2012). Furthermore, peptides RVPSLM and TPSPR generated from egg white proteins were reported to possess potential $\alpha$-glucosidase inhibition with $\mathrm{IC}_{50}$ values of 23.07 and $40.02 \mu \mathrm{mol} / \mathrm{L}$, respectively ( $\mathrm{Yu}$ et al., 2011). Because inhibition of $\alpha$-glucosidase is considered an effective strategy for the control of diabetes by slowing the absorption of glucose, our results indicate that $\mathrm{CWPH}$ that exhibit inhibitory activity of up to $78 \%$ toward $\alpha$-glucosidase could be considered potential antidiabetic agents.

We explored the ability of CWPH to act as $\alpha$-amylase inhibitors to slow down the hydrolysis of starch and production of glucose. $\alpha$-Amylase hydrolyzes the $\alpha$-glycosidic bond in polysaccharides such as glycogen and starch to produce glucose and maltose (Ngoh et al., 2017). Inhibition of $\alpha$-amylase by CWPH generated by gastric and pancreatic enzymes is shown in Figure 4. Inhibition of $\alpha$-amylase by intact whey proteins was lower $(18.72 \% \pm 2.2)$ than that of CWPH generated by gastric and pancreatic enzymes (Figure 4). Inhibition of $\alpha$-amylase activity by $\mathrm{CWPH}$ increased with

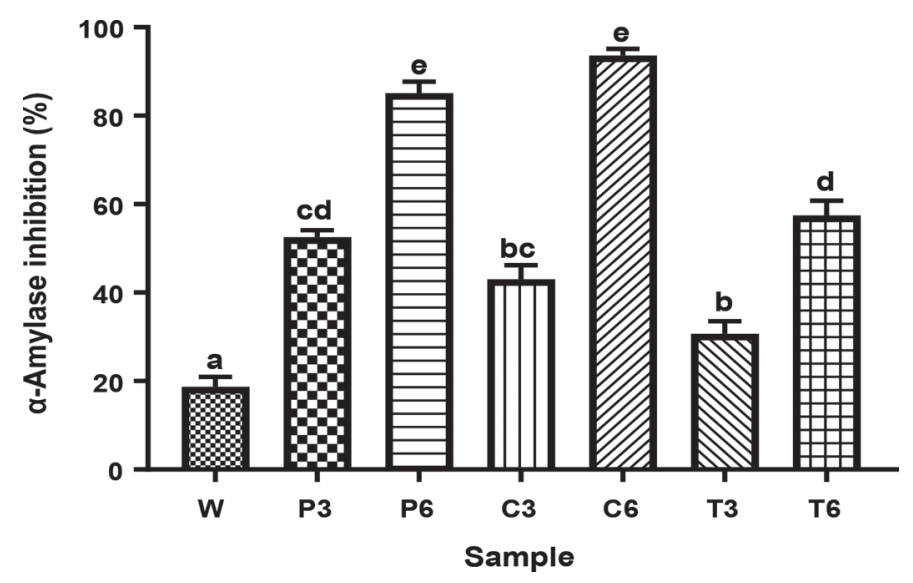

Figure 4. $\alpha$-Amylase inhibitory activity of camel whey protein hydrolysates $(\mathrm{CWPH})$ generated with pepsin, trypsin, and chymotrypsin after 3 and 6 h of hydrolysis (P3, T3, C3, P6, T6, and C6, respectively; $\mathrm{W}=$ unhydrolyzed whey). The concentration of protein in the CWPH was $3 \%$ (wt/vol). Data represent mean $\pm \mathrm{SD}(\mathrm{n}=3)$ from 3 replicates. Different letters $(\mathrm{a}-\mathrm{e})$ on bars represent significant differences among CWPH. 
hydrolysis time (from 3 to $6 \mathrm{~h}$ ) for all hydrolysates $(P<0.05)$, which may due to the release of more $\alpha$-amylase-inhibitory peptides. An increase in the number of shorter peptides will result in the exposure of more terminal groups, which contribute to inhibition of $\alpha$-amylase. After $3 \mathrm{~h}$ of hydrolysis, peptic $\mathrm{CWPH}$ showed the highest inhibition $(53 \% \pm 1.57)$ followed by chymotrypsin-generated $(43.01 \% \pm 3.153)$ and trypsin-generated $(30.72 \% \pm 2.83) \mathrm{CWPH}$. However, at $6 \mathrm{~h}$, inhibition was insignificantly higher $(P>0.05)$ in $\mathrm{C} 6(93.63 \% \pm 1.48)$ than in $\mathrm{P} 6(85.0 \% \pm 2.62)$ and significantly higher than in T6 $(57.45 \% \pm 3.33 ; P<$ $0.05)$. Overall, pepsin- and chymotrypsin-generated hydrolysates demonstrated higher inhibition and trypsingenerated hydrolysates demonstrated lower inhibition of $\alpha$-amylase. Ngoh and Gan (2016) reported $\alpha$-amylase inhibition activity $(15.78 \pm 1.70$ to $52.08 \pm 2.37 \%)$ for pinto bean protein hydrolysates generated by Protomex (Sigma-Aldrich, Malaysia). Yu et al. (2012) previously reported that egg albumin upon hydrolysis with Alcalase showed enhanced $\alpha$-amylase inhibitory activity with $\mathrm{IC}_{50}$ values of $120 \pm 4.0$ and $110 \pm 6.2 \mu \mathrm{mol} / \mathrm{L}$ for peptides KLPGF and EAGVD, respectively. Therefore, consumption of fermented or hydrolyzed food proteins with $\alpha$-amylase and $\alpha$-glucosidase inhibitory activity is currently considered a practical dietary approach to manage hyperglycemia and diabetes (Fujita et al., 2003).

\section{Anticancer Properties of CWPH}

Cell proliferation is a physiological machinery that occurs in almost all tissues under different circumstances. However, uncontrolled cell division can induce tissue proliferation and even cancer. Therefore, the inhibition of cell proliferation is thought to be an effective method for tumor therapy. Anticancer effects of food proteingenerated peptides have been extensively explored and there are several approved peptide-based anticancer drugs (Boohaker et al., 2012). Milk-derived peptides have shown interesting chemoprotective properties. In particular, lactoferrin (a whey protein) has been reported to inhibit the growth of a breast cancer cell line (MDA-MB-231) and nasopharyngeal carcinoma cells by arresting the cell cycle at the $\mathrm{G}_{1}-\mathrm{S}$ transition and suppressing Akt signaling, respectively (Damiens et al., 1999).

In the present study, intact camel whey proteins and CWPH generated with gastric and pancreatic enzymes were explored for their anticancer properties against liver cancer cells (HepG2 cells; Figure 5). The cellular viability in the control samples (cells without any CWPH treatment) was considered to be $100 \%$. Figure $5 \mathrm{a}$ and $5 \mathrm{~b}$ show the antiproliferative effect of pepsin- generated CWPH (3 and $6 \mathrm{~h}$ hydrolysis time, respectively) tested at different concentrations (50-1,000 $\mu \mathrm{g} /$ $\mathrm{mL}$ ) on HepG2 cells. These CWPH showed significant antiproliferative activity by decreasing cancer cell viability in a dose-dependent manner $(P<0.05)$. In both P3 and P6, the maximum inhibitory effect was observed with $1,000 \mu \mathrm{g} / \mathrm{mL}$ protein hydrolysate compared with untreated cells and cells treated with $<400$ $\mu \mathrm{g} / \mathrm{mL} \mathrm{CWPH}$ (Figure 5a and $\mathrm{b} ; P<0.05$ ). These results are in agreement with studies that have found that pepsin-generated camel milk peptides were effective in reducing viability of HepG2 liver cancer cells (Homayouni-Tabrizi et al., 2017). Similarly, cells targeted with $\mathrm{C} 3 \mathrm{CWPH}$ showed significant reduction in viability compared with the untreated cells (Figure 5c). The C3 CWPH also inhibited HepG2 cell viability in a dose-dependent manner with 70 to $80 \%$ viable cells remaining at 50 to $100 \mu \mathrm{g} / \mathrm{mL}$ and $\sim 10 \%$ viable cells at 400 to $1,000 \mu \mathrm{g} / \mathrm{mL}$. The $\mathrm{C} 6 \mathrm{CWPH}$ demonstrated lesser cytotoxicity (more viable cells remaining) than the $\mathrm{C} 3 \mathrm{CWPH}$, with 65 to $75 \%$ viable cells for $\mathrm{C} 6$ and 6.5 to $68 \%$ viable cells for $\mathrm{C} 3 \mathrm{CWPH}$ for the dose ranging from 50 to $1,000 \mu \mathrm{g} / \mathrm{mL}$. Overall, a similar trend of lower viability (higher cytotoxicity) was detected for 3-h than for 6-h hydrolysates for all enzymes tested, indicating that the longer hydrolysis time did not necessarily improve the anticancer properties. Among the different hydrolysates, C3 CWPH had the highest inhibitory effect with only 4.5 to $6.5 \%$ of viable cells remaining after treatment at 400 to $1,000 \mu \mathrm{g} / \mathrm{mL}(P$ $<0.05)$.

Moreover, T3 CWPH demonstrated significant dosedependent inhibition of cell viability in HepG2 cells (Figure 5e). The maximal inhibitory effect (40\%; i.e., $60 \%$ viable cells remaining after treatment compared with the untreated cells; $P<0.05)$ was observed at 800 $\mu \mathrm{g} / \mathrm{mL}$ (Figure $5 \mathrm{f}$ ). For T6 CWPH, the antiproliferative effect against HepG2 cells was found with 60 to $80 \%$ of viable cells remaining when CWPH were applied at a concentration range of 50 to $1,000 \mu \mathrm{g} / \mathrm{mL}$ (Figure 5f). Antiproliferative activity could be related to generation of specific peptides exerting a direct cytotoxic effect on cancer cells, as previously reported for a protein hydrolysate able to induce apoptosis in cancer cells (Homayouni-Tabrizi et al., 2017). Previous reports have mostly focused on whey protein hydrolysates from milks other than camel. For instance, buffalo waste whey (BWW) was reported to demonstrate a $43 \%$ reduction in cell proliferation of H-Caco-2 cells. Peptides isolated from $\mathrm{BWW}$ were reported to produce a significant reduction $(P<0.05)$ of cells in $\mathrm{S}$ phase, and an accumulation of cells in the $\mathrm{G}_{1}$ phase were observed in Caco-2 cells treated with $0.08 \mathrm{mg} / \mathrm{mL}$ BWW for 24 h (De Simone et al., 2009). Moreover, BWW reduced 
H-Caco-2 proliferation by about 30\% compared with the control sample (H-Caco-2 cells untreated with peptide extract; De Simone et al., 2011), with fraction 3 displaying higher antiproliferative activity $(63 \%$ reduction in growth of cells) compared with unfractionated BWW. Furthermore, lactoferricin (a peptide fragment from bovine lactoferrin) has been shown to act against different cancer cell lines through induction of apoptosis, modulation of gene expression, prevention of angiogenesis, and ability to arrest the cell cycle (de Mejia and Dia, 2010). Our results provide a strong basis for further research into whey protein hydrolysates as a potential therapeutic agent for cancer.
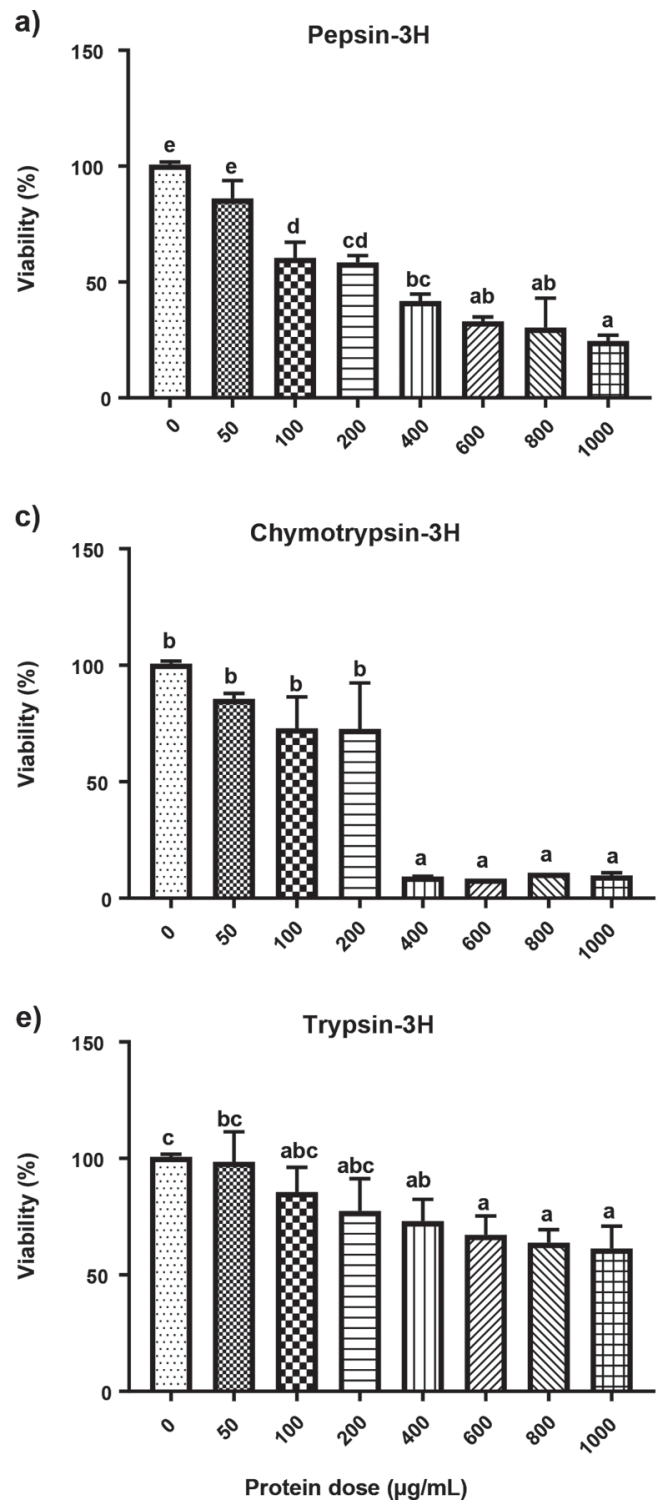

\section{Anti-Inflammatory Activity of CWPH}

Inflammation is a key risk factor for the development of various chronic illnesses such as obesity, diabetes, and tumor progression. Generally, cells affected by inflammation release various pro-inflammatory cytokines that damage DNA, leading to tumor initiation or promotion. Recent reports regarding the potential of milk-derived proteins and their hydrolysates against chronic inflammation prompted us to explore the anti-inflammatory potential of camel milk whey proteins and their hydrolysates (Iskandar et al., 2013). The anti-inflammatory activities of camel whey protein and CWPH (measured
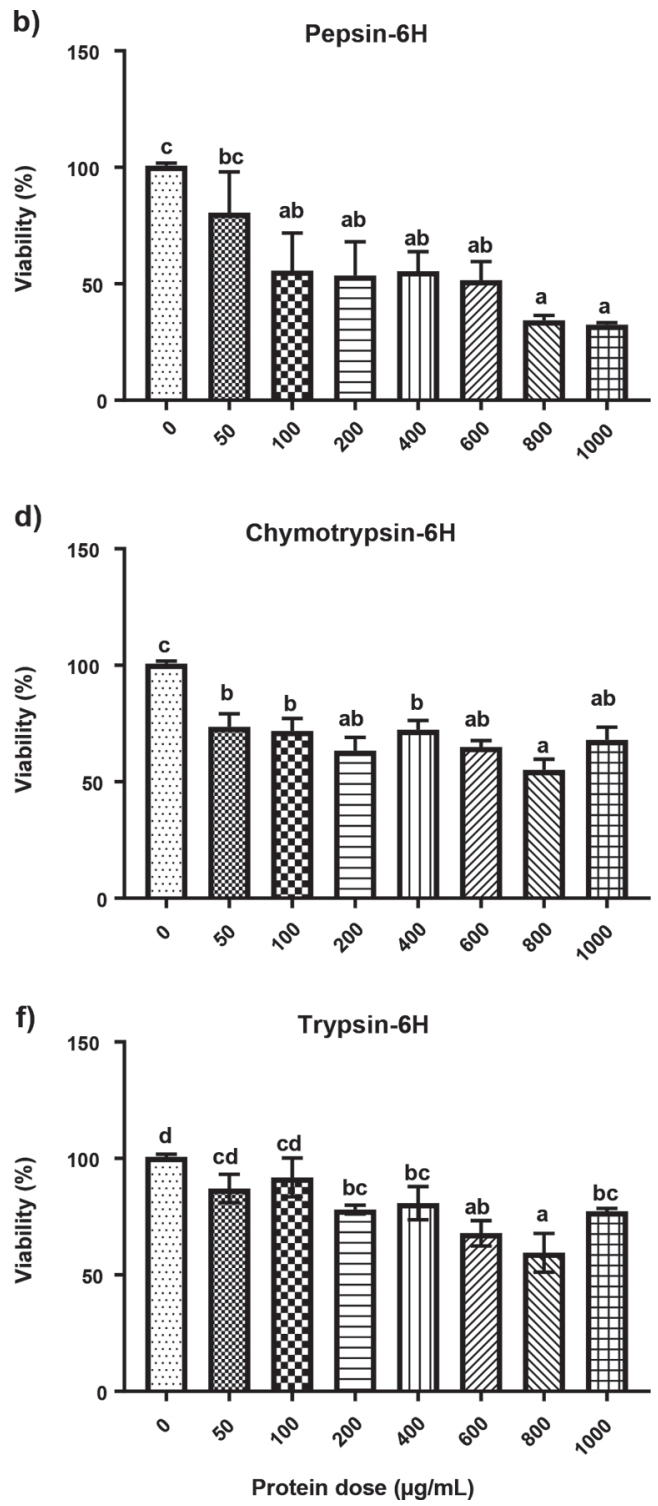

Figure 5. Anticancer activity of camel whey protein hydrolysates (CWPH) generated by gastric and intestinal enzymes against human liver carcinoma cells (HepG2 cells). (a) Pepsin-3H (3-h hydrolysis), (b) pepsin-6H (6-h hydrolysis), (c) chymotrypsin-3H, (d) chymotrypsin-6H, (e) trypsin-3H, and (f) trypsin-6H CWPH. Data represent mean $\pm \mathrm{SD}(\mathrm{n}=3)$ from 3 replicates. Different letters on bars (a-d) represent significant differences among CWPH. 
as diclofenac sodium equivalent capacity; DSEC/mg of protein) are provided in Figure 6. The $\mathrm{P} 6 \mathrm{CWPH}$ had the highest anti-inflammatory activity $(2,841 \mu \mathrm{g} / \mathrm{mL})$, followed by C6 $(2,029 \mu \mathrm{g} / \mathrm{mL})$; P3 had the lowest antiinflammatory activity $(1,342 \mu \mathrm{g} / \mathrm{mL})$ of all treatments, including the unhydrolyzed whey (control). For pepsin and chymotrypsin $\mathrm{CWPH}$, anti-inflammatory activity increased from 3 to $6 \mathrm{~h}$ of hydrolysis. In contrast, trypsin-generated CWPH showed the reverse trend, with high anti-inflammatory activity after $3 \mathrm{~h}$ of hydrolysis followed by a decline at $6 \mathrm{~h}$. Aguilar-Toalá et al. (2017) provided evidence of high anti-inflammatory activity (723.68-1,759.43 $\mu \mathrm{g} / \mathrm{mL}$ of diclofenac sodium equivalents) of peptides derived from fermented bovine milk by the action of specific Lactobacillus plantarum strains. Similarly, Mao et al. (2011) reported that hydrolysis of yak milk caseins with enzymes such as pepsin, trypsin, Alcalase (Novo Nordisk Biochem. Inc., Beijing, China), Flavozyme (Genetic Biochemical Products Ltd., Wuxi, China), and papain resulted in production of peptides with potent anti-inflammatory activity compared with nonhydrolyzed yak caseins. Two peptides, LDAVNR and MMLDF, obtained upon enzymatic hydrolysis of the proteins from the alga Spirulina maxima using gastrointestinal endopeptidases (trypsin, $\alpha$-chymotrypsin, and pepsin) significantly inhibited the release of inflammatory compounds such as histamine and IL-8 (Vo et al., 2013). The inherent anti-inflammatory activity in intact camel whey proteins is in line with other research showing that intact camel milk proteins, especially lac-

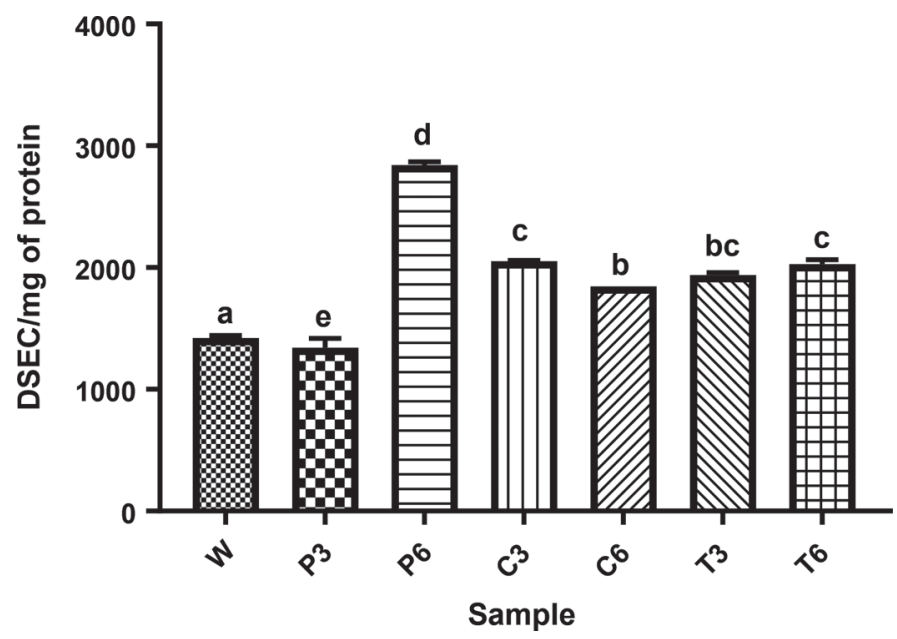

Figure 6. Anti-inflammatory activity of camel whey protein hydrolysates (CWPH) generated with pepsin, trypsin, and chymotrypsin after 3 and 6 h of hydrolysis (P3, T3, C3, P6, T6, and C6, respectively; $\mathrm{W}=$ unhydrolyzed whey). Concentration of the protein in the whey protein hydrolysates was $3 \%(\mathrm{wt} / \mathrm{vol})$. Data represent mean $\pm \mathrm{SD}(\mathrm{n}$ $=3$ ) from 3 replicates. Different letters on bars (a-e) represent significant differences among CWPH. toferrin, exert potent anti-inflammatory action on the host by downregulating the expression of inflammatory cytokines (Arab et al., 2014). Direct evidence regarding anti-inflammatory activities of camel milk hydrolysates is scarce and this study highlights the previously unrecognized anti-inflammatory potential of hydrolysates from enzymatic hydrolysis of camel milk proteins.

\section{CONCLUSIONS}

Camel whey protein hydrolysates showed potential anticancer activity against human liver cancer HepG2 cells, and the anticancer activity was dose-dependent. Of the enzymes tested, hydrolysis for $3 \mathrm{~h}$ with chymotrypsin yielded hydrolysates with the highest anticancer activity. The generated CWPH also showed potential antidiabetic activity by inhibiting DPP-IV, $\alpha$-glucosidase, and $\alpha$-amylase, with $\mathrm{CWPH}$ generated by pepsin and chymotrypsin outperforming those generated by trypsin. We conclude that camel milk whey is a potential source of hydrolysates with promising anticancer, antidiabetic, and anti-inflammatory activities.

\section{ACKNOWLEDGMENTS}

The authors are grateful to United Arab Emirates University for funding this research through a research grant (UPAR-31F094) awarded to Sajid Maqsood. Hassan Mohamed Hassan (Department of Food Science, United Arab Emirates University) is acknowledged for his help in RP-HPLC analysis. The authors declare that they have no conflicts of interest.

\section{REFERENCES}

Abdel Gader, G. M. A., and A. A. Alhaider. 2016. The unique medicinal properties of camel products: A review of the scientific evidence. J. Taibah University Med. Sci. 11:98-103.

Agrawal, R., S. Budania, P. Sharma, R. Gupta, D. Kochar, R. Panwar, and M. Sahani. 2007. Zero prevalence of diabetes in camel milk consuming Raica community of north-west Rajasthan, India. Diabetes Res. Clin. Pract. 76:290-296.

Aguilar-Toalá, J. E., L. Santiago-López, C. Peres, C. Peres, H. Garcia, B. Vallejo-Cordoba, A. Gonzalez-Cordova, and A. HernándezMendoza. 2017. Assessment of multifunctional activity of bioactive peptides derived from fermented milk by specific Lactobacillus plantarum strains. J. Dairy Sci. 100:65-75.

Arab, H. H., S. A. Salama, A. H. Eid, H. A. Omar, E.-S. A. Arafa, and I. A. Maghrabi. 2014. Camel's milk ameliorates TNBS-induced colitis in rats via downregulation of inflammatory cytokines and oxidative stress. Food Chem. Toxicol. 69:294-302.

Badr, G. 2013. Camel whey protein enhances diabetic wound healing in a streptozotocin-induced diabetic mouse model: The critical role of $\beta$-defensin-1,-2 and-3. Lipids Health Dis. 12:46.

Bobe, G., D. C. Beitz, A. E. Freeman, and G. L. Lindberg. 1998. Sample preparation affects separation of whey proteins by reversedphase high-performance liquid chromatography. J. Agric. Food Chem. 46:1321-1325. 
Boohaker, R. J., M. W. Lee, P. Vishnubhotla, J. M. Perez, and A. R. Khaled. 2012. The use of therapeutic peptides to target and to kill cancer cells. Curr. Med. Chem. 19:3794-3804.

Chinedum, E., S. Sanni, N. Theressa, and A. Ebere. 2018. Effect of domestic cooking on the starch digestibility, predicted glycemic indices, polyphenol contents and alpha amylase inhibitory properties of beans (Phaseolus vulgaris) and breadfruit (Treculia africana). Int. J. Biol. Macromol. 106:200-206. https://doi.org/10.1016/j. ijbiomac.2017.08.005.

Damiens, E., I. El Yazidi, J. Mazurier, I. Duthille, G. Spik, and Y. Boilly-Marer. 1999. Lactoferrin inhibits G1 cyclin-dependent kinases during growth arrest of human breast carcinoma cells. J. Cell. Biochem. 74:486-498.

de Mejia, E. G., and V. P. Dia. 2010. The role of nutraceutical proteins and peptides in apoptosis, angiogenesis, and metastasis of cancer cells. Cancer Metastasis Rev. 29:511-528.

De Simone, C., P. Ferranti, G. Picariello, I. Scognamiglio, A. Dicitore, F. Addeo, L. Chianese, and P. Stiuso. 2011. Peptides from water buffalo cheese whey induced senescence cell death via ceramide secretion in human colon adenocarcinoma cell line. Mol. Nutr. Food Res. 55:229-238.

De Simone, C., G. Picariello, G. Mamone, P. Stiuso, A. Dicitore, D Vanacore, L. Chianese, F. Addeo, and P. Ferranti. 2009. Characterisation and cytomodulatory properties of peptides from Mozzarella di Bufala Campana cheese whey. J. Pept. Sci. 15:251-258.

Dryakova, A., A. Pihlanto, P. Marnila, L. Curda, and H. Korhonen. 2010. Antioxidant properties of whey protein hydrolysates as measured by three methods. Eur. Food Res. Technol. 230:865-874.

El-Agamy, E., R. Ruppanner, A. Ismail, C. Champagne, and R. Assaf. 1996. Purification and characterization of lactoferrin, lactoperoxidase, lysozyme and immunoglobulins from camel's milk. Int. Dairy J. 6:129-145.

El-Agamy, E. I., M. Nawar, S. M. Shamsia, S. Awad, and G. F Haenlein. 2009. Are camel milk proteins convenient to the nutrition of cow milk allergic children? Small Rumin. Res. 82:1-6.

Fujita, H., T. Yamagami, and K. Ohshima. 2003. Long-term ingestion of Touchi-extract, an $\alpha$-glucosidase inhibitor, by borderline and mild type-2 diabetic subjects is safe and significantly reduces blood glucose levels. Nutr. Res. 23:713-722.

Homayouni-Tabrizi, M., A. Asoodeh, and M. Soltani. 2017. Cytotoxic and antioxidant capacity of camel milk peptides: Effects of isolated peptide on superoxide dismutase and catalase gene expression. J. Food Drug Anal. 25:567-575.

Horiuchi, N., K. Nakagawa, Y. Sasaki, K. Minato, Y. Fujiwara, K. Nezu, Y. Ohe, and N. Saijo. 1988. In vitro antitumor activity of mitomycin C derivative (RM-49) and new anticancer antibiotics (FK973) against lung cancer cell lines determined by tetrazolium dye (MTT) assay. Cancer Chemother. Pharmacol. 22:246-250.

Hu, F. B. 2011. Globalization of diabetes: The role of diet, lifestyle, and genes. Diabetes Care 34:1249-1257.

Iskandar, M. M., N. Dauletbaev, S. Kubow, N. Mawji, and L. C. Lands. 2013. Whey protein hydrolysates decrease IL-8 secretion in lipopolysaccharide (LPS)-stimulated respiratory epithelial cells by affecting LPS binding to Toll-like receptor 4. Br. J. Nutr. 110:58-68.

Jakubowicz, D., and O. Froy. 2013. Biochemical and metabolic mechanisms by which dietary whey protein may combat obesity and Type 2 diabetes. J. Nutr. Biochem. 24:1-5.

Kahn, S. E., M. E. Cooper, and S. Del Prato. 2014. Pathophysiology and treatment of type 2 diabetes: Perspectives on the past, present, and future. Lancet 383:1068-1083.

Kumar, D., M. K. Chatli, R. Singh, N. Mehta, and P. Kumar. 2016. Antioxidant and antimicrobial activity of camel milk casein hydrolysates and its fractions. Small Rumin. Res. 139:20-25.

Lacroix, I. M., and E. C. Li-Chan. 2013. Inhibition of dipeptidyl peptidase (DPP)-IV and $\alpha$-glucosidase activities by pepsin-treated whey proteins. J. Agric. Food Chem. 61:7500-7506.
Lucas, D. O. 1999. Breakthrough technology produces concentrated whey protein with bioactive immunoglobulins. Clin Nutr Insight $6: 1-4$.

Mao, X.-Y., X. Cheng, X. Wang, and S.-J. Wu. 2011. Free-radicalscavenging and anti-inflammatory effect of yak milk casein before and after enzymatic hydrolysis. Food Chem. 126:484-490.

Mohamad, R. H., Z. K. Zekry, H. A. Al-Mehdar, O. Salama, S. E. ElShaieb, A. A. El-Basmy, M. G. A. M. Al-said, and S. M. Sharawy. 2009. Camel milk as an adjuvant therapy for the treatment of type 1 diabetes: Verification of a traditional ethnomedical practice. J. Med. Food 12:461-465.

Morais, H., L. De Marco, M. Oliveira, and M. Silvestre. 2005. Casein hydrolysates using papain: peptide profile and encapsulation in liposomes. Acta Aliment. 34:59-69.

Moslehishad, M., M. R. Ehsani, M. Salami, S. Mirdamadi, H. Ezzatpanah, A. N. Naslaji, and A. A. Moosavi-Movahedi. 2013. The comparative assessment of ACE-inhibitory and antioxidant activities of peptide fractions obtained from fermented camel and bovine milk by Lactobacillus rhamnosus PTCC 1637. Int. Dairy J. 29:82-87.

Ngoh, Y. Y., and C. Y. Gan. 2016. Enzyme-assisted extraction and identification of antioxidative and a-amylase inhibitory peptides from Pinto beans (Phaseolus vulgaris cv. Pinto). Food Chem. 190:331-337.

Nielsen, P., D. Petersen, and C. Dambmann. 2001. Improved method for determining food protein degree of hydrolysis. J. Food Sci 66:642-646.

Nongonierma, A. B., S. Paolella, P. Mudgil, S. Maqsood, and R. J. FitzGerald. 2017. Dipeptidyl peptidase IV (DPP-IV) inhibitory properties of camel milk protein hydrolysates generated with trypsin. J. Funct. Foods 34:49-58.

Nongonierma, A. B., S. Paolella, P. Mudgil, S. Maqsood, and R. J. FitzGerald. 2018. Identification of novel dipeptidyl peptidase IV (DPP-IV) inhibitory peptides in camel milk protein hydrolysates. Food Chem. 244:340-348.

Salami, M., R. Yousefi, M. R. Ehsani, M. Dalgalarrondo, J.-M. Chobert, T. Haertlé, S. H. Razavi, A. A. Saboury, A. Niasari-Naslaji, and A. A. Moosavi-Movahedi. 2008. Kinetic characterization of hydrolysis of camel and bovine milk proteins by pancreatic enzymes. Int. Dairy J. 18:1097-1102

Silveira, S. T., D. Martínez-Maqueda, I. Recio, and B. HernándezLedesma. 2013. Dipeptidyl peptidase-IV inhibitory peptides generated by tryptic hydrolysis of a whey protein concentrate rich in $\beta$-lactoglobulin. Food Chem. 141:1072-1077.

Uchida, M., Y. Ohshiba, and O. Mogami. 2011. Novel dipeptidyl peptidase-4-inhibiting peptide derived from $\beta$-lactoglobulin. J. Pharmacol. Sci. 117:63-66.

Vo, T.-S., B. Ryu, and S.-K. Kim. 2013. Purification of novel antiinflammatory peptides from enzymatic hydrolysate of the edible microalgal Spirulina maxima. J. Funct. Foods 5:1336-1346.

Yu, Z., Y. Yin, W. Zhao, J. Liu, and F. Chen. 2012. Anti-diabetic activity peptides from albumin against $\alpha$-glucosidase and $\alpha$-amylase. Food Chem. 135:2078-2085

Yu, Z.. Y. Yin, W. Zhao, Y. Yu, B. Liu, J. Liu, and F. Chen. 2011. Novel peptides derived from egg white protein inhibiting alphaglucosidase. Food Chem. 129:1376-1382.

Zhang, B., Z. Deng, D. D. Ramdath, Y. Tang, P. X. Chen, R. Liu, Q. Liu, and R. Tsao. 2015. Phenolic profiles of 20 Canadian lentil cultivars and their contribution to antioxidant activity and inhibitory effects on $\alpha$-glucosidase and pancreatic lipase. Food Chem. $172: 862-872$. 